\title{
Internet Research
}

Modeling utilitarian-hedonic dual mediation (UHDM) in the purchase and use of games

Robert Davis Bodo Lang Neil Gautam

\section{Article information:}

To cite this document:

Robert Davis Bodo Lang Neil Gautam, (2013),"Modeling utilitarian-hedonic dual mediation (UHDM) in the purchase and use of games", Internet Research, Vol. 23 Iss 2 pp. 229 - 256

Permanent link to this document:

http://dx.doi.org/10.1108/10662241311313330

Downloaded on: 15 February 2015, At: 18:02 (PT)

References: this document contains references to 114 other documents.

To copy this document: permissions@emeraldinsight.com

The fulltext of this document has been downloaded 758 times since 2013*

\section{Users who downloaded this article also downloaded:}

Mariola Palazon, Elena Delgado-Ballester, (2013),"Hedonic or utilitarian premiums: does it matter?",

European Journal of Marketing, Vol. 47 Iss 8 pp. 1256-1275 http://dx.doi.org/10.1108/03090561311324318

Robert Davis, Bodo Lang, (2013),"Does game self-congruity increase usage and purchase?", Young Consumers, Vol. 14 Iss 1 pp. 52-66 http://dx.doi.org/10.1108/17473611311305485

Mijeong Noh, Rodney Runyan, Jon Mosier, (2014),"Young consumers' innovativeness and hedonic/ utilitarian cool attitudes", International Journal of Retail \&amp; Distribution Management, Vol. 42 Iss 4 pp. 267-280 http://dx.doi.org/10.1108//JRDM-07-2012-0065

Access to this document was granted through an Emerald subscription provided by 112362 []

\section{For Authors}

If you would like to write for this, or any other Emerald publication, then please use our Emerald for Authors service information about how to choose which publication to write for and submission guidelines are available for all. Please visit www. emeraldinsight. com/ authors for more information.

\section{About Emerald www.emeraldinsight.com}

Emerald is a global publisher linking research and practice to the benefit of society. The company manages a portfolio of more than 290 journals and over 2,350 books and book series volumes, as well as providing an extensive range of online products and additional customer resources and services.

Emerald is both COUNTER 4 and TRANSFER compliant. The organization is a partner of the Committee on Publication Ethics (COPE) and also works with Portico and the LOCKSS initiative for digital archive preservation. 


\title{
Modeling utilitarian-hedonic dual mediation (UHDM) in the purchase and use of games
}

\author{
Robert Davis \\ Faculty of Creative Industries and Business, \\ Department of Management and Marketing, Unitec Institute of Technology, \\ Auckland, New Zealand \\ Bodo Lang \\ Department of Marketing, University of Auckland Business School, \\ Auckland, New Zealand, and \\ Neil Gautam \\ Department of Management and Marketing, \\ Unitec Institute of Technology, Auckland, New Zealand
}

\begin{abstract}
Purpose - It is assumed that consumers consume games to experience hedonic and utilitarian value. However, there is no conceptual model or empirical evidence that supports this hypothesis in the game context or clarifies whether these consumption values have dual mediated or individual effects. Therefore, the purpose of this research is to model the relationship between hedonic and utilitarian consumption and game purchase and usage.

Design/methodology/approach - This research question is answered through two studies. In Study One, qualitative interviews with 18 gamers were implemented to explore the relationship between hedonic and utilitarian consumption and, game purchase and usage behaviour. In Study Two, we surveyed 493 consumers and conducted confirmatory factor analysis and structural equation modelling across four game types to model this relationship.

Findings - The paper concludes that hedonic rather than utilitarian consumption positively impacts purchase and usage. Support was also found for the utilitarian-hedonic dual mediation model (UHDM). Therefore, utilitarian consumption has an indirect causal effect on game purchase or usage through hedonic consumption.

Practical implications - Game development for consumers online, on wireless devices and on consoles should place greater emphasis on the practical implications of hedonic consumption. Attention could be focused on perceived enjoyment, self-concept, self-congruity and self-efficacy as the primary drivers of use and purchase. Practical solutions should also be developed to develop the UHDM effect.

Originality/value - This is the first paper in the game context to explore and model the relationship between hedonic, utilitarian consumption and the UHDM effect on game purchase and usage. This paper is also unique because it provides results across four game groups: all games (ALL), Sports/ Simulation/Driving (SSD), Role Playing Game/Massively Multiplayer Online Role-Playing Game Strategy (RPG), and Action/Adventure/Fighting (AAF).
\end{abstract}

Keywords Utilitarian-hedonic dual mediation model (UHDM), Usage, Purchase, Games, SEM, CFA, Consumers, Consumer behaviour

Paper type Research paper

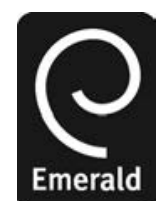

Received 16 September 2012

Revised 16 November 2012

21 December 2012

23 December 2012

Accepted 23 December 2012

\section{9}


INTR

23,2

230

\section{Introduction}

Consumers play computer games on the internet, wireless devices or consoles to experience hedonic and utilitarian consumption value ( $\mathrm{Ng}, 2012)$. To better understand and clarify the relationship between these two consumption values, this research explores and models consumers' game purchase and usage behaviour and experience in terms of hedonic and utilitarian consumption (López and Ruiz, 2011). Understanding this effect is important because games are popular forms of entertainment. For example, US game sales generated \$US 10.5 billion in 2009, \$US 24.75 billion in 2011 and 67 per cent of American households play computer games (Entertainment Software Association (ESA), 2010). Furthermore, the UK market is predicted to grow by 7.5 per cent between 2009 and 2012 (UKIE, 2011). Overall, the sale of games has eclipsed those of the US box-office, cementing gaming as a dominant force of technological consumption and entertainment (Brand, 2010).

This study is also important because it forms one of the first steps in the establishment of the dual mediation hypothesis in the context of games. Mackenzie et al. (1986) and López and Ruiz (2011) argue that both utilitarian and hedonic consumption values have central and peripheral effects on purchase and usage, and that they are entangled rather than being alternatives for one another. Van der Heijden (2004, p. 695) supports this view, arguing that understanding and measuring the relationships between "the productivityoriented (or utilitarian) and pleasure-oriented (or hedonic)" consumption of any IT-based system is vital in the study of user acceptance. Many authors support this view, positing the existence of a mutual relationship, but they admit that there is little empirical evidence to support it (Li et al., 2012; Bridges and Florsheim, 2008). Kücklich (2003) and BuchananOliver and Seo (2012) conclude that while computer gaming is important to academic research, our knowledge of games as a consumption activity is limited.

Most consumer-oriented research has focused on, first, the communication effect (Prugsamatz et al., 2010; Molesworth, 2006); and/or, second, product or brand placement (Cauberghe and De Pelsmacker, 2010; Mackay et al., 2009; Mau et al., 2008). Other researchers, such as Nicovich (2005), have measured consumer involvement and avatar effects on cognition (Jin and Bolebruch, 2009).

Hedonic consumption and utilitarian consumption values and their relationship to each other and to game purchase and usage have not been adequately conceptualized or measured. Therefore, our research question is as follows:

How do we model the relationship between hedonic and utilitarian consumption and game purchase and usage behaviour?

Is this relationship represented as a Utilitarian-Hedonic Dual Mediation Model (UHDM)?

We model these relationships in the context of four game groups that have been defined by Davis and Lang (2012) and Myers (1990): all games (ALL); Sports/Simulation/ Driving (SSD), which places emphasis on hand/eye co-ordination/reflexes in real world environments; Role Playing Game/Massively Multiplayer Online Role-Playing Game/ Strategy (RPG), which places emphasis on characters that gain experience and power through encounters; and Action/Adventure/Fighting (AAF), which places emphasis on simulations of futuristic and historical warfare and/or violent activity. Categorizing games into these four genres is also consistent with Apperley (2006).

\section{Contribution}

The main contribution of this research is the conceptualization and measurement of hedonic and utilitarian value and game purchase and usage behaviour in the context 
of a dual mediation hypothesis. While many authors have proposed this dual Modeling UHDM mediation hypothesis, this research provides empirical evidence to support its relationship in the gaming context. While other authors have provided evidence from an online setting (López and Ruiz, 2011) we extend this model further in gaming. The mutual relationship is important because consumers buy and use games to experience both experiential (hedonic) and goal-directed (utilitarian) behaviours (Wang et al., 2007). In essence, in the same consumption event they seek to achieve known objectives while having no objectives at all. This model will influence game design and play (Choi and Kim, 2004; Kim et al., 2002) and may lead to further questions such as what is the "optimal" flow experience. If it does exist, how are we to conceptualize this "optimal" consumption experience? Do consumers primarily seek the experience of enjoyment and self-concept, or is purchase and usage driven by the utilitarian encounter of the game itself in terms of ease of use, complexity and control?

This paper is organized as follows. First, the conceptual model and hypotheses are developed, placing emphasis on the UHDM model and the antecedents of utilitarian and hedonic consumption. This is followed by the methodology, outlining Study 1 and Study 2. The qualitative and quantitative results of these two studies are presented and then discussed. The paper concludes with managerial and research implications.

\section{Conceptual model}

Figure 1 presents our conceptual models that are differentiated by the dependent variable usage or purchase. The conceptual model is defined as a UHDM model. It is based on the work of Mackenzie et al. (1986, p. 132) with the support of others (López and Ruiz, 2011). They argue that:

The dual mediation hypothesis (DMH), which specifies an indirect flow of causation from [the attitude towards the advertisement] through brand cognitions to [the attitude towards the brand] in addition to the direct effect postulated by the [the attitude towards the advertisement] to [the attitude towards the brand]. Under that specification, perceptions of the source of a message are seen as leading to an attitude toward the source, which in turn governs cognitive and affective reactions to the content of the message. The DMH, then, can

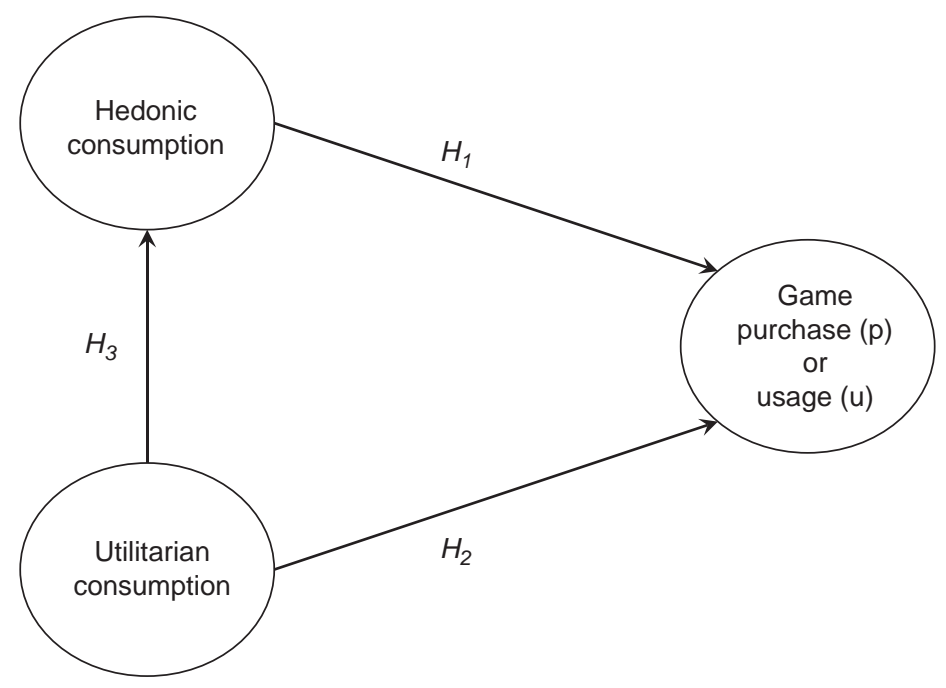

Figure 1. Conceptual model purchase or usage 
INTR

23,2

232 be viewed as asserting the alterative possibility that central and peripheral processes are intertwined rather than substitutes for one another.

In our conceptual model we argue for a UHDM model where, first, utilitarian consumption has an indirect causal effect on game purchase or usage through hedonic consumption $\left(H_{3}\right)$ and second, utilitarian $\left(H_{2}\right)$ and hedonic $\left(H_{1}\right)$ consumption also have a direct effect on game purchase or usage. This hypothesized model is compared to the individual influences model (IIM) that states that utilitarian and hedonic consumption has individual direct effects on game purchase or usage. Therefore, we argue that from the consumption of the game as a valued experience, hedonic and utilitarian consumption are centrally and peripherally intertwined processes (Mackenzie et al., 1986) that drive usage and purchase (Chen, 2009; Holbrook and Hirschman, 1982).

\section{Hedonic consumption}

Our first hypothesis to support the UHDM relates to the importance of hedonic consumption (Childers et al., 2001; Holbrook and Gardner, 1998; Holbrook, 1982). Buying and use motivations depend on the consumer's motivation towards experiential (hedonic) and goal-directed (utilitarian) behaviours (Wang et al., 2007). Wolfinbarger and Gilly (2001) argue that experiential behaviour is associated with a desire to be "entertained, to have fun, and to be immersed in the experience" (p. 46). Therefore, the hedonic experience is often associated with the consumers concern with enjoyment and their self-concept. A hedonic experience, at its extreme, is more subjective and is associated with higher levels of playfulness, which result in positive moods and higher levels of satisfaction (Arnold and Reynolds, 2003).

A hedonic encounter can involve greater interaction, heightened arousal, higher involvement and perceived freedom (Babin et al., 1994). It can also invoke strong feelings, and consumers who shop recreationally often expect high levels of hedonic value (Babin et al., 1994). Gaming generates high levels of emotion and excitement (Fiore et al., 2005) and its environments provide a platform for the experiential amplification of the internal-self (Childers et al., 2001; Scarpi, 2012; Thong and Xu, 2012), subjective interpretation and experimentation (Murray and Bellman, 2011; Fromme, 2003; Eber, 2001). Therefore, we hypothesize for both our usage and purchase models that:

$H_{1 p}$. Hedonic consumption will have a positive effect on game purchase.

$H_{1 u}$. Hedonic consumption will have a positive effect on game usage.

To further define hedonic consumption we argue that its antecedents are the gamer's self-concept (actual, ideal and social), the congruity between self-concept and the game, the self-efficacy of the users in relation to the game and the perceived enjoyment of the game (Babin et al., 1994).

First, self-concept, defined as how consumers perceive and value themselves (Aaker, 1999; Rosenberg, 1979), is important to the discussion of hedonic consumption because of its relationship to self-efficacy and self-congruity. In their play and pursuit of hedonic experience value, consumers will often be led by the interplay (efficacy) between their multiple selves. The desire for interpretation and experimentation arises from the need to transform their self-concept into their ideal, social or gaming state (Johar and Sirgy, 1991). The transformation of self-concept is often lead by influential game characters like "Master Chief" in Halo 4. Like a form of translocative meditation, 
the game permits the consumer to temporarily transform their perceptions of their Modeling UHDM world. Rather than just watching the fight, the consumer can participate and share the experience with their community.

Second, self-congruity is important to hedonic consumption because the subjective experience of imagination is often led by the evaluation of the product/service image vs the consumer's self-concept (Sirgy, 1982; Johar and Sirgy, 1991). It defines the symbolic value that can be obtained from an object (Aguirre-Rodríguez et al., 2012; Quester et al., 2000). Self-congruity is important in a game context because of its impact on imagination and experience. Often gamers will seek a significant gap in the congruity between their own actual perceived self-concept and the ideal self. For example, if we consider the self-image of a gamer and that of "Master Chief" in Halo 4, the gap is significant in time, space and meaning. In the act of play the gamer may wish to temporarily transform their image, thereby escaping the routine of every life: fighting the "Prometheans".

Second, self-efficacy refers to the capability to engage in subjective game play and experience enjoyment (Vorderer, 2003; Eber, 2001; Bandura, 1982). It is important to the concept of hedonic consumption because it is linked to the consumer's evaluation of self-concept: the difference between the actual self (the user's ability to play the game) and the ideal self (the user's ideal ability to play the game). Like self-congruity, the gamer is engaging in reflective evaluation in the process of purchase and usage. For self-efficacy they will seek the evolution of their actual self. The ideal self is often defined by a fictitious character, which is under the restrained and unrestrained control of themselves, the game's technology or social gamer interactions. For example, in the game Halo 4, a key component of the experience is the use of weapons. Being like the "Master Chief" is intimately linked to the consumers' belief that they have the capability to use those weapons effectively and in a way consistent with their in-game character.

Finally, enjoyment defines the game experience as a subjective interpretation (Addis and Holbrook, 2001). Enjoyment is a self-oriented reward that is associated with escapism (Mathwick and Rigdon, 2004), and it has been shown to be a key hedonic determinant (Bridges and Florsheim, 2008). From the literature and our own anecdotal understanding, one of the key motivators that determine consumers to purchase and use games is the hedonic experience of enjoyment. Therefore, we argue that enjoyment is an important antecedent to hedonic consumption.

\section{Utilitarian consumption}

Our conceptual model argues that a dual mediation process is present while consumers are seeking a hedonic experience: they may also be seeking game consumption with known objectives, explicit structure (Huang and Hsieh, 2011; Holbrook and Gardner, 1998) and organized play (Lu and Wang, 2008; Walther, 2003; Prensky, 2001; Frasca, 1999). This type of "recognized ending" (Babin et al., 1994) is important because it defines the game's constraints, ease of use and complexity, and it controls unrestrained exploration (Walther, 2003; Juul, 2001; Jessen, 1999). Utilitarian consumption is defined as being task-oriented, instrumental, rational and efficient. It is also defined by Batra and Ahtola (1991) as an attitude pertaining to the usefulness and value of a particular behaviour exhibited by a consumer. Utilitarian motives usually reflect a "work" mentality (Babin et al., 1994) and are dependent on whether the task at hand has been accomplished. The consumer employing a utilitarian approach will thus experience greater levels of satisfaction once they feel they have made an efficient and purposeful 
INTR

23,2

\section{4}

purchase, especially if it was done in a fastidious manner (Dholakia, 1999). This purchase experience may also be further confirmed and valued if the following game usage supports their task-oriented behaviour. For example, in the consumption of the game Halo 4, utilitarian objectives are essential if the game character "Master Chief" achieves the next game objective. Therefore, it is hypothesized for usage and purchases that:

$H_{2 p}$. Utilitarian consumption will have a positive effect on game purchase.

$H_{2 u}$. Utilitarian consumption will have a positive effect on game usage.

Utilitarian consumption is defined further in the game context as: ease of use (Batra and Ahtola, 1991), complexity (Walther, 2003; Juul, 2001; Jessen, 1999) and perceived control (Lu and Wang, 2008; Prensky, 2001; Frasca, 1999). These constructs are used because of their predominance in the gaming literature and because they have received some of the strongest conceptual and empirical support in utilitarian consumption (Batra and Ahtola, 1991).

First, ease of use affects utilitarian consumption because the game has specific rules and goal-oriented outcomes that can only be followed and achieved if the consumer can control and manipulate it (Newman, 2004). Ease of use is "the degree to which a person believes that using a particular system would be free of effort" (Davis, 1989, p. 320). This conceptualization has been supported by many researchers (Vijayasarathy, 2004; Venkatesh et al., 2003) and it argues that if a game is easier to use, the consumer will perceive its consumption to be less complex.

Second, perceived complexity is important because for consumers to follow the game structure and achieve their aims, game play barriers need to be overcome in order to attain utilitarian consumption (Igbaria and Iivari, 1995). This may include barriers related to the game's learning processes and usability (Ong, 2004). Perceived complexity "reflects perceptions of internal and external constraints on behaviour [...]" (Venkatesh et al., 2003, p. 454). In other words, it cannot arise if a game is too complex. High complexity may disrupt the consumers' experience of the flow state (Hoffman and Novak, 2009).

Finally, perceived control plays an important role in utilitarian consumption as it reflects the consumer's ability to control the experience (Huang and Hsieh, 2011). Control will vary across different contexts (Gentry and Calantone, 2002) and is also dependent on the "level of one's control over the environment and one's actions" (Koufaris, 2002, p. 208). It is argued that when consumers perceive that they can control a game, they will also perceive that the game will be easier to use and will be less complex.

\section{Dual mediation hypothesis}

Based on our earlier discussion of the conceptual model and the UHDM hypothesis (López and Ruiz, 2011) we present our final hypothesis, which specifies the relationship between utilitarian and hedonic consumption. This is supported by Overby and Eun-Ju (2006) and Kivetz (2000), who argue that consumers often seek a balance between hedonic and utilitarian motivation in the consumption experience. Jones et al. (2006) and Raynolds et al. (2012) also support this view, citing the complex interrelationships between hedonic and utilitarian experience, usage and purchase behaviour. The empirical relationship between hedonic consumption and utilitarian consumption was 
first proposed by Batra and Ahtola (1991), with support from Crowley et al. (1992). Modeling UHDM More recently other researchers have supported this view, conceptually as well as empirically. For example:

(1) Voss et al. (2003) developed a combined hedonic/utilitarian (HED/UT) scale;

(2) Bridges and Florsheim (2008) suggest that online marketers offer both hedonic and functional experiences together to maximize use and purchase behaviour;

(3) Rintamäki et al. (2006) also developed a tripartite conceptualization of customer value based on the integration of utilitarian, social and hedonic value; and

(4) Li et al. (2012) propose a stimulus-organism-response (S-O-R)-based model that incorporates both the utilitarian and hedonic factors of consumers.

In games, if the reality of utilitarian consumption does not exist, then the play associated with hedonic consumption will be unconstrained: leading to meaninglessness uncontrolled activity. Without the co-existence of hedonic and utilitarian consumption, the gamer may not be able to adequately control their character, the game environment, the tools or the minions of the "warriors" under their direct orders as the "commander". This view is supported by Buchanan-Oliver and Seo (2012), who argued that, in the context of Warcraft III, the utilitarian rules of the game created opportunities for the co-creation of hedonic play consumption. In essence, rules create order for escapism. Therefore, it is hypothesized for both our usage and purchase models:

$H_{3 p}$. Utilitarian consumption will have a positive effect on game purchase mediated by hedonic consumption.

$H_{3 u}$. Utilitarian consumption will have a positive effect on game usage mediated by hedonic consumption.

\section{Method}

To explore and measure our conceptual model we implemented two studies. Study 1 is qualitative and exploratory in nature. The aim of this study is to explore our hypothesized relationships, which also creates further validation of our model. Study 2 consists of a model development process using questionnaire data that is analysed by using confirmatory factor analysis (CFA) and structural equation modelling (SEM).

\section{Study 1}

Study 1 can best be described as a case study of consumers (Miles and Huberman, 1994). The advantage of this method is that "this type of empirical inquiry suits an investigation into the contemporary phenomena from a real life context" (Yin, 1994, p. 13). In essence, our approach promotes a process of theory development (Eisenhardt, 1989) and a further exploration of the conceptual model and hypotheses. Therefore, it has a complementary effect on Study 2. Table I provides the characteristics of our participants.

From an operational perspective, our method was based on a series of one-to-one indepth interviews with 18 participants. All interviews were conducted at the premises of the participant's work place and interviews lasted between 30 and 90 minutes. To reduce the risk of manipulation, participants were not given prior knowledge of the questions. Interviews were recorded and transcribed verbatim. The validity and 
INTR

23,2

236

Age

Marital Status

Annual income
Study 2

Education

Employment

Gender
Age

Ethnicity

Table I.

Participant characteristics (\%) - Study 1 and 2

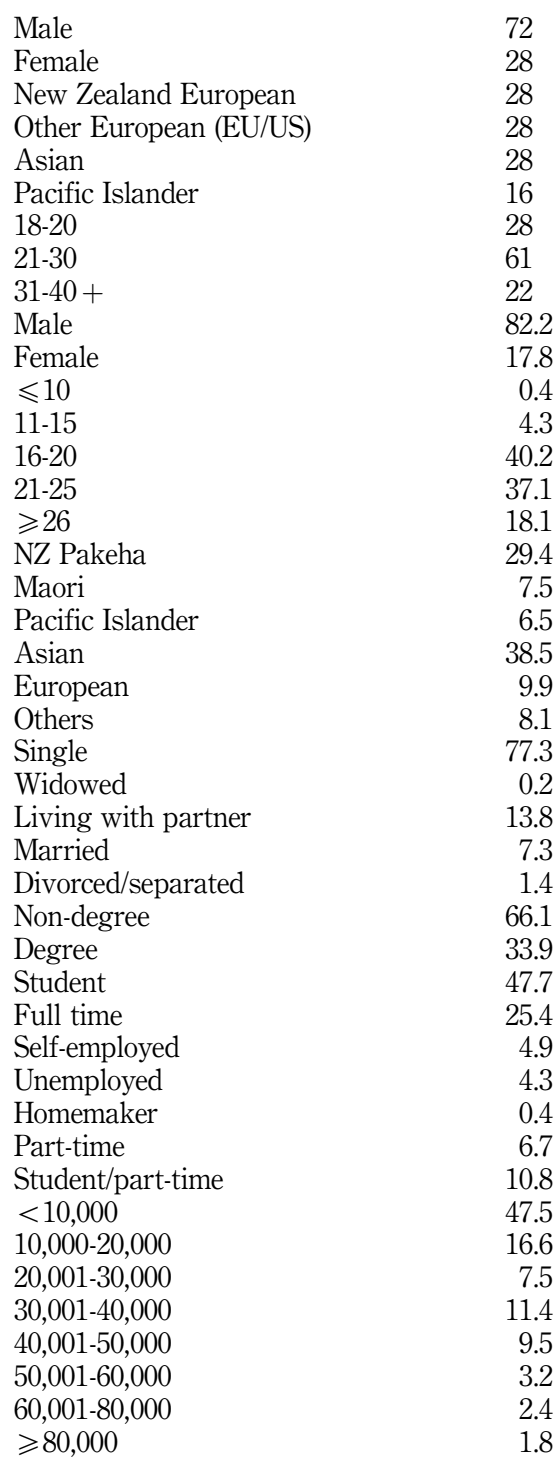

reliability of the case study was tested by controlling the two characteristic risks that are associated with the case study design (Yin, 1994). The first area of concern relates to the interviewer's readiness and training as well as the ideological position of the interviewer. To minimize interviewer bias, a single experienced interviewer was used. To maintain the integrity of data analysis for parsimonious theory building (Eisenhardt, 1989), two researchers were used to analyse the evidence. The primary researcher conducted coding protocols in accordance with the research questions, whilst the second researcher ensured that the analysis was consistent with the 
research design. A thematic analysis method was used to analyse the text units against Modeling UHDM the hypotheses in accordance with the procedures outlined by Miles and Huberman (1994).

Study 2

Data were gathered through face-to-face interviews with 493 consumers in Auckland, New Zealand from the general public (Lu and Wang, 2008) using a structured survey (Appendix). Intercept interviews were conducted in four locations in Auckland: east, west, south, north. These locations were approximately 30 kilometres from the Auckland City centre. Every potential respondent was asked to participate so that they would have an equal chance to participate in the survey. Interviewers then interacted with the potential respondent and after finishing the interview they would approach the next potential respondent. Those that agreed to participate were asked to respond to a structured questionnaire. Respondents were screened by means of two questions, first, in the last week, did you play games on your computer (PC or MAC), or on a games console (perhaps through the internet), such as an Xbox, PlayStation or Wii that you purchased? If the answer was "yes", they were asked, second, which game did you play most often in the last week? Question 1 established that the respondent was a regular player of the games they had actually purchased and Question 2 ensured that respondents had mostly played a game that was not preloaded on a computer such as Solitaire. The sample showed (Table I) that 493 respondents provided usable data (77 per cent), were 25 years and under, 66 per cent of the respondents had not received a degree, 77 per cent were single. In all, 39 per cent of the respondents were Asians and 48 per cent of the respondents were students, 48 per cent of the respondents have an annual income of $<\$ 10,000$ and 82 per cent of the respondents were male and 18 per cent were female. To make the completion of the questions easier for respondents, a seven-point Likert scale was used to measure the constructs of interest ( 1 = "strongly disagree", 7 = "strongly agree").

Utilitarian consumption value is operationalized as:

(1) perceived ease of use (Venkatesh et al., 2003);

(2) perceived control (Venkatesh et al., 2003); and

(3) perceived complexity (Venkatesh et al., 2003; Vijayasarathy, 2004).

Hedonic consumption value is operationalized as:

(1) self-concept (Helgeson and Supphellen, 2004; Sirgy et al., 1997);

(2) self-congruence (Helgeson and Supphellen, 2004);

(3) self-efficacy (Vijayasarathy, 2004; Venkatesh et al., 2000, 2003; Koufaris, 2002; Venkatesh and Davis, 1996); and

(4) perceived enjoyment (Venkatesh, 2000; Koufaris, 2002).

\section{Analysis \\ Study 1}

Our findings suggest that the relationship between hedonic consumption and game usage and purchase could relate to factors such as the need for the experience of an impulsive purchase, to be nostalgic and to satisfy the desire to capture a bargain. As there are always many other game alternatives, participants argued that the relationship between hedonic consumption, usage and purchase is often concerned 
INTR

23,2

238 with getting the right offer to the consumer at the right time and place, both within the game experience and in relation to online environments (e.g. online game retailers and communities). It is important that these offers take into account key demographics. Game marketers with specific knowledge of their consumers and a customer relationship management philosophy will be able to leverage this understanding to achieve such customized offers. For example, knowing that the consumer associates a positive experience with consuming products that are aligned to their interests.

In terms of the relationship between utilitarian consumption and game usage, consumers argue that a game can be viewed as the achievement of a series of goals. This iterative process drives future intentions and actual usage. In some ways it is a sub-process of interactivity. Participants argued that each time a goal is achieved through consumption, there is a "payoff". It is argued that this payoff is mostly likely related to the cognitive value gained from the utilitarian consumption experience. It was suggested by participants that for game purchase, the technology of the game in terms of "bugs" is a constant disruptor or mediator of this value.

Participants also highlighted the relationship between utilitarian and hedonic consumption in both usage and purchase contexts: the duality of experience and immersion vs the set game-related objectives of the technology-led "new innovation". In essence there appears to be an interrelation between the hedonic immersion, which appears to have no end, and the experience defined by a utilitarian outcome. It would appear that both are important in game consumption value and that, depending on factors such as technology, the hedonic and/or utilitarian state are able to change and potentially switch. In the purchase context, participants argued for the importance of the game's technology: how it was valued and experienced and how it could lead to purchase. Central to the argument is the personality of the consumer and how the technology enables that personality to interact with the game environment.

For the relationship between utilitarian consumption and ease of use in a usage context, participants argued that game innovations, while they changed the nature of interactivity, are built on fundamental mechanics that are easy to use. It is possible that the consumers had the same underlying objectives in the consumption experience, but through new ways of interacting with the environment, the value of the consumption was enhanced. In some ways it was the old and the new: the familiar and the unfamiliar. It was argued by participants that ease of use was not only about the game and play, but was also related to game channels such as Steam in the usage and purchase context. There appears to be an important seamless integration between game, channel and transaction. It is argued that with brands like Steam, who market their own games as well as those from other platforms, the integration between game, channel and transaction is oriented around consumer objectives. Thus, ease of use may drive utilitarian consumption.

When discussing the relationship between utilitarian consumption and perceived complexity in game usage, it was argued by participants that a key value driver in gaming was the complexity of the challenge. A reward is derived from solving the objective, which is inherent in the complex challenge. Optimal value from a utilitarian perspective is derived when the consumers' "skill sets" are constantly being flexed by the complexity and challenge that are almost infinite. Participants viewed utilitarian value, complexity and purchase as a constant clamour for a unique "new" experience. In this way, utilitarian experience is like the "fuel" to the "fire" (hedonic experience).

It was suggested by participants that in the relationship between utilitarian consumption and perceived control in game usage, the main objective is to get to the 
next level against the "competitor" through determination and having control over the Modeling UHDM skills required. It was also suggested that there was a need to explore and, in a sense, be out of control. From a purchase perspective, control is about commitment to a game and its serious and very specific consumption. The level of response is compared to other games in which hedonic consumption is enhanced but the consumer does not have any specific goal or direction in mind.

The relationship between hedonic consumption and self-congruity in game usage was argued by participants from the perspective of the consumer's character and how that image evolves and makes conflicting choices dynamically, for example, in the choice to "quest". For the consumer, fun and fantasy can be gained from this depth, and it may be different from the consumer's own self-concept: "It is like watching a novel being written". Even though the multiple selves diverge and the narrative expands, there has to be congruence of the consumer's own self-concept or ideal state to continue to engage in the transactions.

When discussing the relationship between hedonic consumption and self-efficacy in game usage, participants argued strongly for a belief in their ability to accomplish a task and their ability to play the game. Reference was made to the team. In essence, the goal is to win, to progress and experience enjoyment and excitement. For hedonic consumption and self-efficacy in the game purchase, we cite the importance of future rewarding gaming experiences with "greater and greater challenges as time went on". Consumers will purchase games that enhance gaming skills.

In hedonic consumption, self-concept plays a key role in usage and purchase as games are often played not only to experience self-concept in different ways, but also to expand these perceptions to multiple selves through "different feelings and choices they make". It was argued by participants that there has to be a link between self-concept and the alternative self. Consistency might also include morality. If the psychic distance is too great, there will be a large gap between skills and challenges and this may disrupt the optimal experience and flow state. Hence, "that can make the game less enjoyable".

Anecdotally, it is a commonly held view that consumers use and buy games because of the relationship between hedonic consumption and perceived enjoyment. However, it was argued by participants that this type of value was more complex and possibly a multidimensional concept. The state of enjoyment does not mean having everything a consumer wants. Rather, it is defined by what is meant by fulfilment and choice, indicating that consumers have a lot of control over perceived enjoyment, and that they define it according to the higher order cognitive state that they desire. As argued, purchase is closely aligned to a game that satisfies this state of enjoyment.

\section{Study 2}

With Study 2, the analysis adopted a two-stage process of model development and testing (Bagozzi and Yi, 2012) using AMOS 19. First, the measurement model was developed using a CFA (Kline, 1998). Testing our hypotheses followed, using SEM. In this process two models were developed and tested purchase and usage.

CFA. Before the CFA was implemented the data were cleaned for missing values, outliers and normality to maintain consistency with the assumptions of CFA and SEM (Hair et al., 1998). Appendix shows the original questionnaire with notation of variables removed in all phases of the data cleaning and model modification. Outliers were assessed using the Mahalanobis distance statistic with observations removed where both $\mathrm{p} 1$ and $\mathrm{p} 2$ were significant. Normality was tested with measures of skewness and kurtosis. Variables with a kurtosis and skewness value of $> \pm 2.0$ were deleted (Curran 
INTR

23,2

240 et al., 1996). Multicollinearity was also measured, with variables of a variance inflation factor $>5$ being deleted (Curto and Pinto, 2011). The final sample size was 350 for the purchase model and 326 for the usage model. Differences in the sample size are attributed to further observation removal for the Mahalanobis distance statistic in the usage model data set. For both the purchase and usage model, further model refinements were made to determine the optimal measurement model through deletion of observed variables with a standardized residual covariance of $>2.0$ (Hair et al., 2010). Correlations between variables were also determined to ensure that they support single rather than multiple constructs (Bagozzi and Yi, 2012).

At the completion of the modifications, the observed independent variables of the purchase and usage models were identical. However, our model measured purchase and usage across four game groups concurrently and in our questionnaire these constructs are measure differently, for our dependent observed variables: for usage we used summated mean measures of game platform (PG4= PU1, PU2, PU3, PU4, PU5) and usage (UALL = PU8, PU9, PU10, PU11, PU12, PU15, PU16, PU17, PU18) and for purchase summated mean measures of purchase across SSD (PSSD = PB10, PB16, $\mathrm{PB} 18), \mathrm{RPG}(\mathrm{PRPG}=\mathrm{PB} 14, \mathrm{~PB} 15, \mathrm{~PB} 17)$, and $\mathrm{AAF}(\mathrm{PAAF}=\mathrm{PB} 8, \mathrm{~PB} 9, \mathrm{~PB} 11)$.

For the CFA measurement model, the results for discriminant validity, convergent validity and goodness-of-fit $(\mathrm{GoF})$ are shown in Tables II-V. We conclude for both our purchase and usage models that they have discriminant and convergent validity as well as acceptable GoF. Our measures of validity and fit are based on Bagozzi and Yi (2012) and others (Hair et al., 2010; Baumgartner and Homburg, 1996; Hu and Bentler, 1995; Bacon et al., 1995; Browne and Cudeck, 1993; Bentler, 1990), that is:

(1) discriminant validity: the implied correlations for each construct are less than the corresponding square root of the average variance extracted (AVE).

(2) convergent validity: construct Cronbach's $\alpha$ and Construct reliability are $>0.70$ and the AVE is $>0.50$ (Fornell and Larcker, 1981; Nunnally, 1978).

(3) GoF: CMIN/df ( $\chi^{2} /$ degrees of freedom) ratio is $<5.0$, a significant $p$-value, normalized fit index (NFI), comparative fit index (CFI) and Tucker Lewis index (TLI) is preferably $>0.95$ and, that the root mean square error of approximation (RMSEA) and standardized root mean-squared residual (SRMR) is preferably $<0.05$, but values up to 0.08 are acceptable.

SEM. The SEM focused on the analysis of the structural conceptual model using the maximum likelihood method to test the hypothesized relationships between the second-order constructs and purchase or usage (Figure 1). In our structural model we did not specify in the results and hypotheses the first-order observer variables for hedonic consumption (self-concept, self-congruity, self-efficacy and perceived enjoyment) and utilitarian consumption (ease of use, perceived control and perceived complexity). This is because these variables are all well-accepted theoretical models with high measures of reported construct validity across a variety of contexts.

In our SEM there are four forms of this model:

(1) all games (ALL);

(2) SSD;

(3) RPG; and

(4) AAF. 


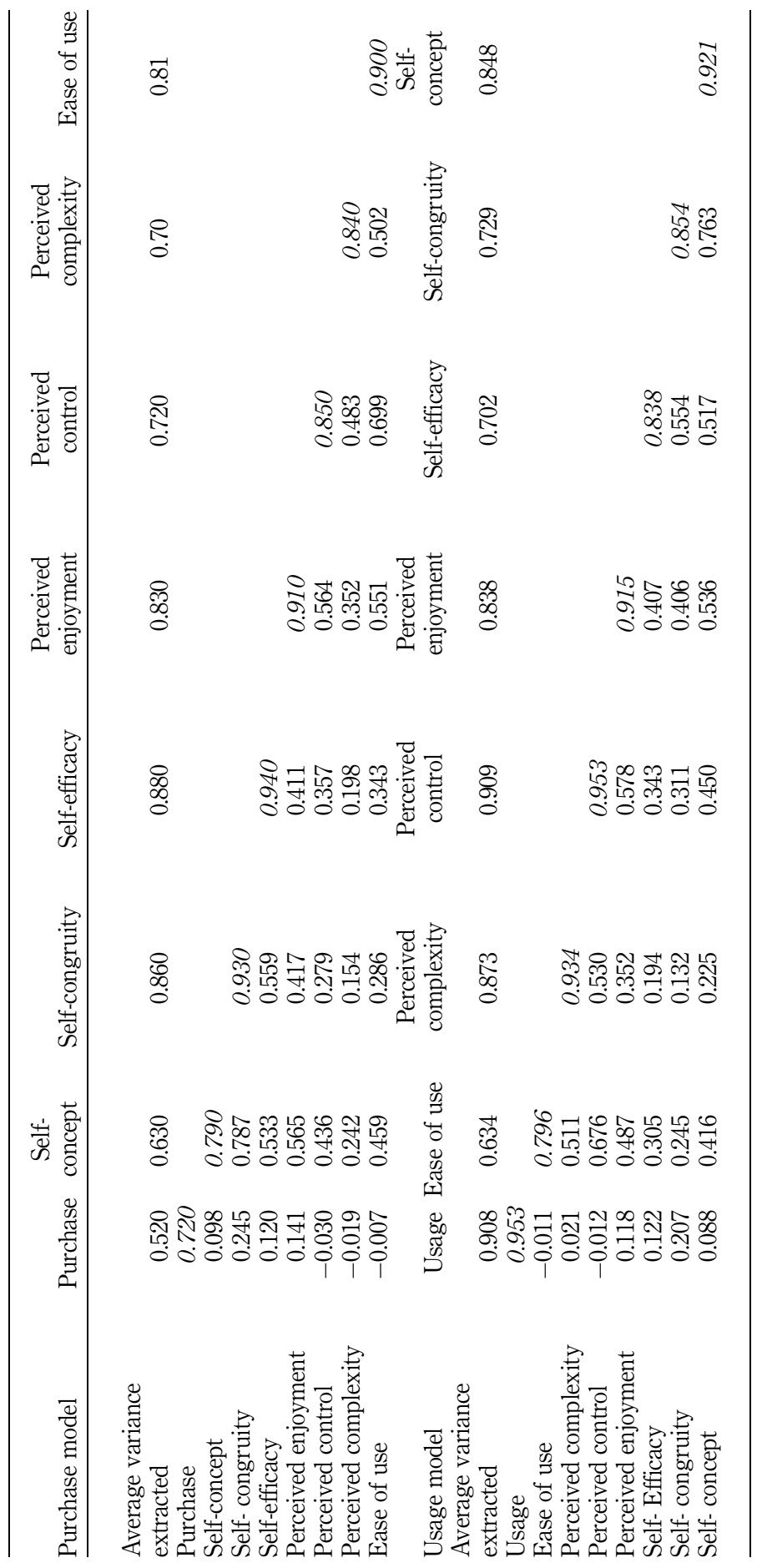

Modeling UHDM

241

Table II. Discriminant validity purchase and usage models 
INTR

23,2

\begin{tabular}{|c|c|c|c|c|c|c|}
\hline Purchase model & Factor & Loading & $p$ & $\begin{array}{c}\text { Cronbach } \\
\alpha\end{array}$ & $\begin{array}{l}\text { Construct } \\
\text { reliability }\end{array}$ & $\begin{array}{c}\text { Average variance } \\
\text { extracted }\end{array}$ \\
\hline \multirow[t]{3}{*}{ Purchase } & PSSD & 0.813 & $<0.001$ & 0.755 & 0.760 & 0.520 \\
\hline & PRPG & 0.601 & $<0.001$ & & & \\
\hline & PAAF & 0.738 & $<0.001$ & & & \\
\hline \multirow[t]{3}{*}{ Self-concept } & CON1 & 0.668 & $<0.001$ & 0.817 & 0.840 & 0.630 \\
\hline & CON3 & 0.827 & $<0.001$ & & & \\
\hline & CON4 & 0.874 & $<0.001$ & & & \\
\hline \multirow[t]{3}{*}{ Self- congruity } & $\mathrm{SC} 3$ & 0.944 & $<0.001$ & 0.948 & 0.950 & 0.860 \\
\hline & $\mathrm{SC} 2$ & 0.945 & $<0.001$ & & & \\
\hline & $\mathrm{SC} 1$ & 0.898 & $<0.001$ & & & \\
\hline \multirow[t]{3}{*}{ Self-efficacy } & SE14 & 0.875 & $<0.001$ & 0.955 & 0.940 & 0.880 \\
\hline & SE15 & 0.968 & $<0.001$ & & & \\
\hline & SE16 & 0.968 & $<0.001$ & & & \\
\hline \multirow[t]{4}{*}{ Perceived enjoyment } & ENJ8 & 0.896 & $<0.001$ & 0.951 & 0.950 & 0.830 \\
\hline & ENJ6 & 0.914 & $<0.001$ & & & \\
\hline & ENJ5 & 0.958 & $<0.001$ & & & \\
\hline & ENJ4 & 0.878 & $<0.001$ & & & \\
\hline \multirow[t]{3}{*}{ Perceived control } & $\mathrm{PC} 4$ & 0.838 & $<0.001$ & 0.873 & 0.880 & 0.720 \\
\hline & PC3 & 0.951 & $<0.001$ & & & \\
\hline & $\mathrm{PC} 2$ & 0.744 & $<0.001$ & & & \\
\hline \multirow[t]{3}{*}{ Perceived complexity } & PX4R & 0.692 & $<0.001$ & 0.867 & 0.870 & 0.700 \\
\hline & PX3R & 0.958 & $<0.001$ & & & \\
\hline & PX2R & 0.844 & $<0.001$ & & & \\
\hline \multirow[t]{4}{*}{ Ease of use } & PE5 & 0.886 & $<0.001$ & 0.943 & 0.940 & 0.810 \\
\hline & $\mathrm{PE} 4$ & 0.923 & $<0.001$ & & & \\
\hline & PE3 & 0.893 & $<0.001$ & & & \\
\hline & PE2 & 0.892 & $<0.001$ & & & \\
\hline
\end{tabular}

Table III.

Convergent validity (purchase model)
242

The primary aim of the SEM stage is to specify the model and formally state the nature of the relationships through the hypotheses $\left(H_{1}, H_{2}\right.$ and $\left.H_{3}\right)$. To adapt our model for each game form we manipulated the mean summated game type purchase and usage variable. Tables V and VI show the results of our SEM using the same GoF as in the CFA with the addition of the standardized regression weight, path estimate, critical ratio and $p$-value for level of significance. Table VII also summarizes the squared multiple correlations.

We conclude the following:

(1) GoF is acceptable for all for game forms.

(2) Hedonic consumption is positively related to game purchase but not for RPG, and AAF.

(3) Hedonic consumption is positively related to game usage but not for AAF and RPG.

(4) Utilitarian consumption is not positively related to game purchase or usage.

(5) Utilitarian consumption is positively related to hedonic consumption in game purchase or usage. 


\begin{tabular}{|c|c|c|c|c|c|c|c|}
\hline Usage model & Factor & Loading & $p$ & $\begin{array}{c}\text { Cronbach } \\
\alpha \\
\end{array}$ & $\begin{array}{l}\text { Construct } \\
\text { reliability }\end{array}$ & $\begin{array}{c}\text { Average variance } \\
\text { extracted }\end{array}$ & \\
\hline Usage & PG4 & 0.950 & $<0.001$ & 0.949 & 0.952 & 0.908 & \\
\hline \multirow[t]{3}{*}{ Ease of use } & $\begin{array}{l}\text { UALL } \\
\text { PE5 }\end{array}$ & $\begin{array}{l}0.956 \\
0.939\end{array}$ & $\begin{array}{l}<0.001 \\
<0.001\end{array}$ & 0.943 & 0.837 & 0.634 & \\
\hline & $\mathrm{PE} 4$ & 0.943 & $<0.001$ & & & & 243 \\
\hline & PE3 & 0.880 & $<0.001$ & & & & \\
\hline \multirow[t]{3}{*}{ Perceived complexity } & PX4R & 0.733 & $<0.001$ & 0.883 & 0.954 & 0.873 & \\
\hline & PX3R & 0.956 & $<0.001$ & & & & \\
\hline & PX2R & 0.858 & $<0.001$ & & & & \\
\hline \multirow[t]{3}{*}{ Perceived control } & $\mathrm{PC} 4$ & 0.819 & $<0.001$ & 0.862 & 0.965 & 0.909 & \\
\hline & PC3 & 0.951 & $<0.001$ & & & & \\
\hline & PC2 & 0.729 & $<0.001$ & & & & \\
\hline \multirow[t]{4}{*}{ Perceived enjoyment } & ENJ8 & 0.913 & $<0.001$ & 0.953 & 0.954 & 0.838 & \\
\hline & ENJ6 & 0.923 & $<0.001$ & & & & \\
\hline & ENJ5 & 0.947 & $<0.001$ & & & & \\
\hline & ENJ4 & 0.877 & $<0.001$ & & & & \\
\hline \multirow[t]{3}{*}{ Self- efficacy } & SE14 & 0.901 & $<0.001$ & 0.967 & 0.875 & 0.702 & \\
\hline & SE15 & 0.978 & $<0.001$ & & & & \\
\hline & SE16 & 0.979 & $<0.001$ & & & & \\
\hline \multirow[t]{3}{*}{ Self- congruity } & $\mathrm{SC} 3$ & 0.955 & $<0.001$ & 0.800 & 0.889 & 0.729 & \\
\hline & $\mathrm{SC} 2$ & 0.955 & $<0.001$ & & & & \\
\hline & $\mathrm{SC} 1$ & 0.892 & $<0.001$ & & & & \\
\hline \multirow[t]{2}{*}{ Self- concept } & CON1 & 0.661 & $<0.001$ & 0.818 & 0.944 & 0.848 & Table IV. \\
\hline & $\begin{array}{l}\text { CON3 } \\
\text { CON4 }\end{array}$ & $\begin{array}{l}0.829 \\
0.882\end{array}$ & $\begin{array}{l}<0.001 \\
<0.001\end{array}$ & & & & $\begin{array}{l}\text { Convergent validity } \\
\text { (usage model) }\end{array}$ \\
\hline
\end{tabular}

(6) To test for our UHDM we specified our structural models but removed $\mathrm{H}_{3}$. In essence, this creates an IMM. Overall, we reject this model because in each replication across purchase, usage and game types the GoF measures deteriorated and the SRMR result increased well above the accepted criteria. Therefore, when comparing the UHDM with the IMM, the UHDM is accepted.

\section{Discussion}

We conclude that hedonic rather than utilitarian consumption positively impacts purchase and usage (Yang, 2010; Addis and Holbrook, 2001). Therefore, $H_{1}$ is accepted. The consumption value of gaming as an entertainment form is reinforced and can be associated with enjoyment, self-concept, self-efficacy and self-congruity (Lu and Wang, 2008; Babin et al., 1994). Consumers purchase and use games because they value an internal cognitive experience of variability and multiple outcomes, which is only prejudiced by the consumer's instant emotions. It is interesting to explore why consumers play and use games for the hedonic experiential value they provide, based on a discussion of the literature. The consumers need for hedonic consumption may be driven by their self-concept (Aaker, 1999; Sirgy, 1982) and the desire to achieve a high congruity between their actual, ideal and social self-concept and that of the game. Transformation could be motivated by the promise of an alternative self-concept through developing new gaming skills and esteem value; being seen to be playing the latest game; joining others who are playing a particular game on the internet; escapism 


\section{INTR 23,2}

\section{4}

Table V.

CFA and SEM goodness of fit $(\mathrm{GoF})$ - (purchase and usage model) utilitarianhedonic dual mediation model (UHDM) vs individual influences model (IIM)
Model CMIN/DF

NFI TLI CFI RMSEA SRMR Accept/reject

$\begin{array}{llllllllll} & & & & & & & & & \\ \text { Purchase (UHDM) } & \text { CFA } & 2.010 & <0.001 & 0.935 & 0.959 & 0.966 & 0.054 & 0.044 & \text { Accept } \\ & \text { SEM ALL } & 2.068 & <0.001 & 0.930 & 0.958 & 0.963 & 0.047 & 0.052 & \text { Accept } \\ & \text { SEM SSD } & 2.019 & <0.001 & 0.935 & 0.958 & 0.963 & 0.049 & 0.052 & \text { Accept } \\ & \text { SEM RPG } & 2.018 & <0.001 & 0.937 & 0.961 & 0.966 & 0.047 & 0.050 & \text { Accept } \\ \text { Usage (UHDM) } & \text { SEM AAF } & 2.148 & <0.001 & 0.936 & 0.960 & 0.965 & 0.048 & 0.057 & \text { Accept } \\ & \text { CFA } & 2.121 & <0.001 & 0.941 & 0.961 & 0.968 & 0.059 & 0.037 & \text { Accept } \\ & \text { SEM ALL } & 2.217 & <0.001 & 0.925 & 0.952 & 0.957 & 0.050 & 0.054 & \text { Accept } \\ & \text { SEM SSD } & 2.272 & <0.001 & 0.935 & 0.956 & 0.962 & 0.051 & 0.051 & \text { Accept } \\ & \text { SEM RPG } & 2.169 & <0.001 & 0.937 & 0.960 & 0.965 & 0.040 & 0.049 & \text { Accept } \\ \text { Purchase (IIM) } & \text { SEM AAF } & 2.296 & <0.001 & 0.934 & 0.956 & 0.961 & 0.050 & 0.051 & \text { Accept } \\ & \text { SEM ALL } & 2.234 & <0.001 & 0.922 & 0.948 & 0.954 & 0.052 & 0.119 & \text { Reject } \\ & \text { SEM SSD } & 2.496 & <0.001 & 0.926 & 0.948 & 0.954 & 0.055 & 0.127 & \text { Reject } \\ & \text { SEM RPG } & 2.417 & <0.001 & 0.928 & 0.950 & 0.956 & 0.054 & 0.126 & \text { Reject } \\ & \text { SEM AAF (IIM) } & 2.583 & <0.001 & 0.923 & 0.944 & 0.951 & 0.057 & 0.138 & \text { Reject } \\ & \text { SEM ALL } & 2.489 & <0.001 & 0.916 & 0.941 & 0.948 & 0.055 & 0.116 & \text { Reject } \\ & \text { SEM SSD } & 2.594 & <0.001 & 0.925 & 0.945 & 0.952 & 0.057 & 0.122 & \text { Reject } \\ & \text { SEM RPG } & 2.501 & <0.001 & 0.927 & 0.948 & 0.955 & 0.055 & 0.122 & \text { Reject } \\ & \text { SEM AAF } & 2.629 & <0.001 & 0.924 & 0.944 & 0.951 & 0.058 & 0.122 & \text { Reject }\end{array}$

Notes: CFA, confirmatory factor analysis; SEM, structural equation model, CMIN/DF, $\chi^{2} /$ degrees of freedom ratio; NFI, normed fit index; TLI, Tucker Lewis index; CFI, comparative fit index; RMSEA, root-mean-square error of approximation; SRMR, Standardized root-mean-squared residual. $p$ significance $<0.001$

(Funk and Buchman, 1996), wanting to assume a different personality; or at the most extreme level, facilitating a personality shift (Boyle and Hibberd, 2005; Anderson and Bushman, 2002; Dill and Dill, 1998).

We also believe that there is some consistency with Molesworth (2006), who found that the consumer's consumption is a rich experience that links real life with the reality of the game and helps develop the consumer's imagination. Our findings suggest that, for these types of games, consumers value the power they have and the encounters they gain by assuming "a simulated character", as well as the effect that this has on their self-concept. In essence, the consumer is gaining self-image value, which represents the value that the person applies to a specific self-concept. The consumer gains value from multiple self-concepts, with the two most common being the actual self and the ideal self. It is proposed that a "gaming-self" exists, which represents the consumer's perception of him/herself as both a game player and a virtual game character. According to the multidimensionality principle, the gaming-self will vary depending on the type of game that the consumer is interacting with. In this research, the gaming-self, embodied in the consumer's self-concept of the virtual game character, is of significant value to the consumer. Hedonic consumption is also related to the consumer's need for enjoyment (Chtourou and Souiden, 2010; Beuningen van et al., 2009) and self-congruity. Kang et al. (2009) found that self-congruity has post-adoption belief effects, that is, that self-congruity explains usage (Sirgy et al., 2008). The symbolic value gained from playing games may drive a process of evaluation that leads to usage and purchase. Koo (2009) suggests that while previous studies have focused on extrinsic values in experiential consumption, intrinsic experiential motives such as self-congruity are important motivators for consumers to play games (Lu and Wang, 2008). 


\begin{tabular}{|c|c|c|c|c|c|c|c|c|}
\hline & Model & Hypothesis & $\begin{array}{l}\text { Standardizec } \\
\text { regression } \\
\text { weight }\end{array}$ & Estimate & $\begin{array}{l}\text { Critical } \\
\text { ratio }\end{array}$ & $\begin{array}{c}\text { Significance } \\
(p)\end{array}$ & $\begin{array}{l}\text { e Accept/ } \\
\text { reject }\end{array}$ & \\
\hline \multirow[t]{11}{*}{ Purchase (UHDM) } & SEM ALL & $H_{1 p}$ & 0.160 & 0.260 & 2.244 & 0.025 & Accept & \\
\hline & & $\begin{array}{l}H_{2 p} \\
H_{3 p}\end{array}$ & $\begin{array}{r}-0.089 \\
0.492\end{array}$ & $\begin{array}{r}-0.169 \\
0.579\end{array}$ & $\begin{array}{r}-1.105 \\
5.484\end{array}$ & $<0.001$ & Accept & 245 \\
\hline & SEM SSD & $H_{1 p}$ & 0.163 & 0.305 & 2.577 & 0.010 & Accept & \\
\hline & & $H_{2 p}$ & -0.087 & -0.193 & -1.321 & 0.186 & Reject & \\
\hline & & $H_{3 p}$ & 0.491 & 0.582 & 5.483 & $<0.001$ & Accept & \\
\hline & SEM RPG & $H_{1 p}$ & 0.074 & 0.148 & 1.222 & 0.222 & Reject & \\
\hline & & $H_{2 p}$ & 0.059 & 0.137 & 0.916 & 0.359 & Reject & \\
\hline & & $H_{3 p}$ & 0.493 & 0.571 & 5.474 & $<0.001$ & Accept & \\
\hline & SEM AAF & $H_{1 p}$ & 0.093 & 0.194 & 1.511 & 0.131 & Reject & \\
\hline & & $H_{2 p}$ & -0.091 & -0.219 & -1.353 & 0.176 & Reject & \\
\hline & & $H_{3 p}$ & 0.493 & 0.572 & 5.474 & $<0.001$ & Accept & \\
\hline \multirow[t]{11}{*}{ Usage (UHDM) } & SEM ALL & $H_{1 u}$ & 0.172 & 0.217 & 1.958 & 0.050 & Accept & \\
\hline & & $\mathrm{H}_{2 u}$ & -0.042 & $\begin{array}{r}-0.063 \\
-0572\end{array}$ & -0.482 & 0.630 & Reject & \\
\hline & SEM SSD & $\begin{array}{l}H_{3 u} \\
H_{1 u}\end{array}$ & $\begin{array}{l}0.489 \\
0.149\end{array}$ & $\begin{array}{l}0.513 \\
0.274\end{array}$ & $\begin{array}{l}5.420 \\
2.376\end{array}$ & $\begin{array}{r}<0.001 \\
0.018\end{array}$ & $\begin{array}{l}\text { Accept } \\
\text { Accept }\end{array}$ & \\
\hline & & $H_{2 u}$ & -0.080 & -0.174 & -1.216 & 0.224 & Reject & \\
\hline & & $H_{3 u}$ & 0.488 & 0.578 & 5.424 & $<0.001$ & Accept & \\
\hline & SEM RPG & $H_{1 u}$ & 0.117 & 0.242 & 1.932 & 0.053 & Reject & \\
\hline & & $H_{2 u}$ & 0.090 & 0.217 & 1.387 & 0.166 & Reject & \\
\hline & & $H_{3 u}$ & 0.490 & 0.571 & 5.400 & $<0.001$ & Accept & \\
\hline & SEM AAF & $H_{1 u}$ & 0.047 & 0.099 & 0.771 & 0.441 & Reject & \\
\hline & & $H_{2 u}$ & 0.010 & 0.025 & 0.155 & 0.877 & Reject & \\
\hline & & $H_{3 u}$ & 0.490 & 0.569 & 5.388 & $<0.001$ & Accept & \\
\hline \multirow[t]{8}{*}{ Purchase (IIM) } & SEM ALL & $H_{1 p}$ & 0.166 & 0.264 & 2.626 & 0.009 & Accept & \\
\hline & & $H_{2 p}$ & -0.073 & -0.134 & -1.094 & 0.274 & Reject & \\
\hline & SEM SSD & $H_{1 p}$ & 0.170 & 0.316 & 3.035 & 0.002 & Accept & \\
\hline & & $H_{2 p}$ & -0.072 & -0.154 & -1.249 & 0.212 & Reject & \\
\hline & SEM RPG & $H_{1 p}$ & 0.090 & 0.178 & 1.680 & 0.093 & Reject & \\
\hline & & $H_{2 p}$ & 0.062 & 0.138 & 1.090 & 0.276 & Reject & \\
\hline & SEM AAF & $H_{1 p}$ & 0.074 & 0.155 & 1.407 & 0.159 & Reject & \\
\hline & & $H_{2 p}$ & -0.090 & -0.196 & -1.461 & 0.144 & Reject & \\
\hline \multirow[t]{8}{*}{ Usage (IIM) } & SEM ALL & $H_{1 u}$ & 0.182 & 0.234 & 2.320 & 0.020 & Accept & Table VI. \\
\hline & & $H_{2 u}$ & -0.032 & -0.047 & -0.413 & 0.680 & Reject & Structural model \\
\hline & SEM SSD & $H_{1 u}$ & 0.157 & 0.285 & 2.814 & 0.005 & Accept & hypotheses - (purchase \\
\hline & & $H_{2 u}$ & -0.066 & -0.138 & -1.153 & 0.249 & Reject & and usage models) \\
\hline & SEM RPG & $H_{1 u}$ & 0.131 & 0.265 & 2.420 & 0.016 & Accept & utilitarian-hedonic dual \\
\hline & & $H_{2 u}$ & 0.095 & 0.220 & 1.652 & 0.098 & Reject & mediation model (UHDM) \\
\hline & SEM AAF & $H_{1 u}$ & 0.045 & 0.094 & 0.845 & 0.398 & Reject & vs individual influences \\
\hline & & $H_{2 u}$ & 0.016 & 0.037 & 0.267 & 0.790 & Reject & model (IIM) \\
\hline
\end{tabular}

It is also interesting to understand why consumers' do not value utilitarian consumption, since $\mathrm{H}_{2}$ is rejected. This hypothesis specifies the positive effect of utilitarian consumption on usage and purchase. It would seem logical to assume that, with ease of use, the consumer's ability to interact with the game would be enhanced and the perceived and actual barriers to interaction would be reduced (Yang, 2010; Liao and Shi, 2009). We suggest that the gaming industry is relatively mature and sophisticated, and game designers could have discovered an appropriate level of ease of use for games. This could disrupt the optimal flow state: the game is too easy so the 
INTR

23,2

246

Table VII.

Squared multiple correlations $\left(R^{2}\right)$ (purchase and usage models)

\begin{tabular}{|c|c|c|c|c|}
\hline & Model & Construct & $\begin{array}{c}\text { Squared multiple } \\
\text { correlations (UHDM) }\end{array}$ & $\begin{array}{l}\text { Squared multiple } \\
\text { correlations (IIM) }\end{array}$ \\
\hline \multirow[t]{12}{*}{ Purchase } & \multirow[t]{3}{*}{ SEM ALL } & Hedonic & 0.242 & 0.000 \\
\hline & & Utilitarian & 0.000 & 0.000 \\
\hline & & Purchase & 0.020 & 0.033 \\
\hline & \multirow{3}{*}{ SEM SSD } & Hedonic & 0.241 & 0.000 \\
\hline & & Utilitarian & 0.000 & 0.000 \\
\hline & & Purchase & 0.020 & 0.034 \\
\hline & \multirow{3}{*}{ SEM RPG } & Hedonic & 0.243 & 0.000 \\
\hline & & Utilitarian & 0.000 & 0.000 \\
\hline & & Purchase & 0.013 & 0.012 \\
\hline & \multirow[t]{3}{*}{ SEM AAF } & Hedonic & 0.242 & 0.000 \\
\hline & & Utilitarian & 0.000 & 0.000 \\
\hline & & Purchase & 0.006 & 0.014 \\
\hline \multirow{12}{*}{ Usage } & \multirow{3}{*}{ SEM ALL } & Hedonic & 0.239 & 0.000 \\
\hline & & Utilitarian & 0.000 & 0.000 \\
\hline & & Usage & 0.024 & 0.034 \\
\hline & \multirow[t]{3}{*}{ SEM SSD } & Hedonic & 0.239 & 0.000 \\
\hline & & Utilitarian & 0.000 & 0.000 \\
\hline & & Usage & 0.017 & 0.029 \\
\hline & \multirow[t]{3}{*}{ SEM RPG } & Hedonic & 0.240 & 0.000 \\
\hline & & Utilitarian & 0.000 & 0.000 \\
\hline & & Usage & 0.032 & 0.026 \\
\hline & \multirow[t]{3}{*}{ SEM AAF } & Hedonic & 0.240 & 0.000 \\
\hline & & Utilitarian & 0.000 & 0.000 \\
\hline & & Usage & 0.003 & 0.002 \\
\hline
\end{tabular}

Note: Cohen (1988, p. 413) notes that $R^{2} \approx 0.0196$ is a small effect, 0.13 is a medium effect and 0.26 is considered large

consumer does not enjoy the game because they are not continually challenged (Hoffman and Novak, 2009). Second, the fairly generic nature of game hardware and software controls may be another reason why ease of use may not be an important contributor to utilitarian goals and purchase or usage (Dabholkar and Sheng, 2009). One issue is the extent of control over the game interface vs the game play.

For the positive relationship between utilitarian and hedonic consumption, $H_{3}$ is accepted. In further support of the dual mediation hypothesis we argue that to optimize the game experience, the consumer should have limited control over how the hedonic experience is created. Value is optimized in the consumption act when the consumer perceives that the game, the other participants and the environment determine the experience. For the consumers to value the consumption experience of the game, they must have a sense of control so that they are able to control the characters that gain experience and power through encounters. However, control may also not reflect the consumers' need to control the game experience as they could also perceived that control may constrain how they want to shape the interaction.

It would also seem logical to assume that, by experiencing complexity, the consumer's ability to interact with the game would be enhanced by the reduction of the perceived and actual barriers to interaction (Trujillo et al., 2010; Dellaert and Stremersch, 2005). Competent consumers may not consider complexity to be an important contributing factor in their purchase and usage decisions (D'Astous and 
Guevremont, 2008). This may be partly caused by expert consumers' ability to interact Modeling UHDM with and master complex games, thus reducing their perception of the games' complexity. In other words, complexity is game-specific as well as an individual difference variable. The more experienced consumer is less likely to notice the high complexity of certain games, due to their extensive exposure to similar games. This process may be self-reinforcing, with the consumer starting out with generally less complex games from which they migrate to games that are increasingly complex to play and to master. Complexity in this sense may stretch across a number of dimensions, such as the number of objectives to be solved, the difficulty of each challenge (Huang and Hsieh, 2011), and the number of characters to interact with. In this sense, some consumers may be consciously or unconsciously "chasing complexity" to satisfy their continuously growing ability to handle complex games.

\section{Managerial implications}

Game design should place more emphasis on hedonic consumption rather than utilitarian value in consumption behaviour. For example, self-concept: it is not a question of which self the consumers perceive themselves to be but what self they wish to escape into. Game characters may help transform the consumers' self-concept. For example, game development may start with a questioning of the consumers' desired altered self and then construct characters based on this feedback. Such moves need to go beyond allowing consumers to design the visual representation of their characters. The ability to adapt the behavioural traits of characters will further the consumers' ability to identify with their character, and this will appeal more strongly to their selfconcept, thus facilitating game usage and purchase behaviour. Furthermore, games could be deployed across multiple channels to simulate interactivity between the characters in the game and the consumer (Davis and Sajtos, 2008). For example, Huang and Hsieh (2011) suggest that there is a link between games and social network services. For online service-oriented games, there may be a need for the whole service experience to be closely monitored in terms of its consistency with self-congruity. This is because of the inherent intangibility and variability of services as well as the rapid change in the online environment. Finally, by understanding the motives of usage and purchase the social harm related to games may be minimized (Chen et al., 2005). Finally, the strategies of game-play and marketing should seek to practically apply the UHDM model.

\section{Future research and limitations}

Future research may wish to ascertain the applicability of the results to other geographical areas and should also extend the model into other samples that are different from the New Zealand context. It is also important to test the dual mediation hypothesis for different products or services. As the gamer plays an important role in the consumption process, further research is required to explore and measure the effects of co-creation and co-production on the consumption experience. With the recent release of immersive games like Halo 4, the co-creation and co-production of the games' hedonic and utilitarian narrative will provide important insights. Finally, much attention has been given to consumption during actual game play, so exploratory work is required on game play when a consumer is not interacting with a game. For example, when they are not playing, what are their thought processes and narratives during the day? It could be argued that grouping the games together in terms of genre type is a limitation of the data analysis. However, we believe that grouping the games is 
INTR

23,2

248 appropriate as they can exhibit similar characteristics and thus represent similar acts of consumption. Our study also differentiated between game types but did not examine the differences between online and offline gaming. Given that this conceptual model is new within this research context, further exploration may also help to uncover other relevant measures of hedonic and utilitarian consumption that were not deployed in this study.

We also note that because this is the first time the UHDM model has been conceptualized and measured in a game context. Therefore, to develop a generalizable theory, further work will be required to develop the measurement and structural models. For example:

(1) the reporting of total and indirect effects of utilitarian consumption on game purchase or usage through hedonic consumption $\left(H_{3}\right)$;

(2) the seven antecedent variables and their contribution to the model. Consideration should also be given to additional variable not tested in this research; and

(3) greater investigation and justification of the current second-order factor model following Koufteros et al. (2009).

\section{References}

Aaker, J.L. (1999), "The malleable self: the role of self-expression in persuasion", Iournal of Marketing Research, Vol. 36 No. 1, pp. 45-57.

Addis, M. and Holbrook, M.B. (2001), "On the conceptual link between mass customization and experiential consumption: an explosion of subjectivity", Journal of Consumer Behaviour. Vol. 1 No. 1, pp. 50-66.

Aguirre-Rodríguez, A., Bosnjak, M. and Sirgy, J. (2012), "Moderators of the self-congruity effect on consumer decision-making: a meta-analysis", Journal of Business Research, Vol. 65 No. 8, pp. 1179-88.

Anderson, C.A. and Bushman, B.J. (2002), "Human aggression”, Annual Review of Psvchology, Vol. 53, pp. 27-51.

Apperley, T.H. (2006), "Genre and game studies: toward a critical approach to video game genres", Simulation and Gaming, Vol. 37 No. 1, pp. 6-23.

Arnold, M.J. and Reynolds, K.E. (2003), "Hedonic shopping motivations”, Journal of Retailing, Vol. 79 No. 2, pp. 77-95.

Babin, B.J., Darden, W.R. and Griffin, M. (1994), "Work and/or fun: measuring hedonic and utilitarian shopping value", Iournal of Consumer Research, Vol. 20 No. 4, pp. 644-56.

Bacon, D.R., Paul, L. and Murray, Y. (1995), "Composite reliability in structural equations modelling", Educational and Psychological Measurement, Vol. 55 No. 3, pp. 394-406.

Bagozzi, R. and Yi, Y. (2012), "Specification, evaluation, and interpretation of structural equation models", Journal of the Academy of Marketing Science, Vol. 40 No. 1, pp. 8-34.

Bandura, A. (1982), "Self-efficacy mechanism in human agency", American Psychologist, Vol. 37 No. 2, pp. 122-47.

Batra, R. and Ahtola, O.T. (1991), "Measuring the hedonic and utilitarian sources of consumer attitudes”, Marketing Letters, Vol. 2 No. 2, pp. 159-70.

Baumgartner, H. and Homburg, C. (1996), "Applications of structural equation modelling in marketing and consumer research: a review", International Iournal of Research in Marketing, Vol. 13 No. 2, pp. 139-61. 
Bentler, P.M. (1990), "Comparative fit indexes in structural models", Psychological Bulletin, Modeling UHDM Vol. 107 No. 2, pp. 238-46.

Beuningen van, J., de Ruyter, K., Wetzels, M. and Streukens, S. (2009), "Customer self-efficacy in technology - based self-service”, Journal of Service Research, Vol. 11 No. 4, pp. 407-28.

Boyle, R. and Hibberd, M. (2005), Review of Research on the Impact of Violent Computer Games on Young People, Her Majesty's Department of Trade and Industry/Department of Culture, Media and Sport, London.

Brand, J. (2010), "National research prepared by bond university for the interactive games and entertainment association", available at: www.igea.net/2010/08/interactive-new-zealand2010-inz10/ (accessed January 2011).

Bridges, E. and Florsheim, R. (2008), "Hedonic and utilitarian shopping goals: the online experience”, Journal of Business Research, Vol. 61 No. 4, pp. 309-14.

Browne, M.W. and Cudeck, R. (1993), "Alternative ways of assessing model fit", in Bollen, K.A. and Long, S.J. (Eds), Testing Structural Equation Models, Sage, Newbury Park, CA, pp. 136-62.

Buchanan-Oliver, M. and Seo, Y. (2012), "Play as co-created narrative in computer game consumption: the hero's journey in Warcraft III", Journal of Consumer Behaviour, Vol. 11 No. 6, pp. 423-31.

Cauberghe, V. and De Pelsmacker, P. (2010), "Advergames: the impact of brand prominence and game repetition on brand responses", Iournal of Advertising, Vol. 31 No. 1, pp. 5-18.

Chen, Y. (2009), "Possession and access: consumer desires and value perceptions regarding contemporary art collection and exhibit visits", Iournal of Consumer Research, Vol. 35 No. 6, pp. 925-40.

Chen, Y.-C., Chen, P.S., Hwang, J.-J., Korba, L., Song, R. and Yee, G. (2005), “An analysis of online gaming crime characteristics", Internet Research, Vol. 15 No. 3, pp. 246-61.

Childers, T.L., Carr, C.L., Peck, J. and Carson, S. (2001), "Hedonic and utilitarian motivations for online shopping behaviour”, Journal of Retailing, Vol. 77 No. 4, pp. 511-35.

Choi, D. and Kim, J. (2004), "Why people continue to play online games: in search of critical design factors to increase customer loyalty to online contents", Cuberpsychology and Behaviour, Vol. 7 No. 1, pp. 11-24.

Chtourou, M.S. and Souiden, N. (2010), "Rethinking the TAM model: time to consider fun", Journal of Consumer Marketing, Vol. 27 No. 4, pp. 336-44.

Cohen, J. (1988), Statistical Power Analysis for the Behavioural Sciences, Erlbaum, Hillsdale, NJ.

Crowley, A., Spangenberg, E. and Hughes, K. (1992), "Measuring the hedonic and utilitarian dimensions of attitudes toward product categories", Marketing Letters, Vol. 3 No. 3, pp. 239-49.

Curran, P.J., West, S.G. and Finch, J.F. (1996), "The robustness of test statistics to non-normality and specification error in confirmatory factor analysis", Psvchological Methods, Vol. 1 No. 1, pp. 16-29.

Curto, J.D. and Pinto, J.C. (2011), "The corrected VIF (CVIF)", Journal of Applied Statistics, Vol. 38 No. 7, pp. 1499-507.

Dabholkar, P.A. and Sheng, X. (2009), "The role of perceived control and gender in consumer reactions to download delays", Journal of Business Research, Vol. 62 No. 7, pp. 756-60.

D'Astous, A. and Guevremont, A. (2008), "Effects of retailer post-purchase guarantee policies on consumer perceptions with the moderating influence of financial risk and product complexity", Journal of Retailing and Consumer Services, Vol. 15 No. 4, pp. 306-14.

Davis, F.D. (1989), "Perceived usefulness, perceived ease of use, and consumer acceptance of information technology", MIS Quarterlv Vol. 13 No. 3, pp. 319-40. 
INTR

23,2

250
Davis, R. and Lang, B. (2012), "Modelling the effect of self-efficacy on game usage and purchase behaviour", Iournal of Retailing and Consumer Services, Vol. 19 No. 7, pp. 67-77.

Davis, R. and Sajtos, L. (2008), "Measuring consumer interactivity in response to campaigns coupling mobile and television media", Lournal of Advertising Research, Vol. 48 No. 3, pp. 375-91.

Dellaert, B.G.C. and Stremersch, S. (2005), "Marketing mass-customized products: striking a balance between utility and complexity", Iournal of Marketing Research, Vol. 42 No. 2, pp. 219-27.

Dholakia, R.R. (1999), "Going shopping: key determinants of shopping behaviours and motivations", International Journal of Retail and Distribution, Vol. 27 No. 4, pp. 154-63.

Dill, K.E. and Dill, J.C. (1998), "Video game violence: a review of the empirical literature", Aggression and Violent Behaviour: A Review Iournal, Vol. 3 No. 4, pp. 407-28.

Eber, D.E. (2001), “Towards computer game aesthetics - editorial”, Digital Creativity, Vol. 12 No. 3, pp. 129-32.

Eisenhardt, K.M. (1989), "Building theories from case study research", Academv of Management Review, Vol. 14 No. 4, pp. 532-50.

Entertainment Software Association (ESA) (2010), "Industry facts", available at: www. theesa.com/facts/index.asp (accessed 23 February 2011).

Fiore, A., Jin, H. and Kim, J. (2005), "For fun and profit: hedonic value from image interactivity and responses toward an online store", Psychology and Marketing, Vol. 22 No. 8, pp. 669-94.

Fornell, C. and Larcker, D.F. (1981), "Evaluating structural equation models with unobservable variables and measurement error", Journal of Marketing Research, Vol. 18 No. 1, pp. 39-50.

Frasca, G. (1999), "Ludology meets narratology: similtude and differences between (video) games and narrative", Parnasso, available at: www.ludology.org/articles/ludology.htm (accessed May 2010).

Fromme, J. (2003), “Computer games as a part of children's culture”, International Journal of Computer Game Research, Vol. 3 No. 1, available at: www.gamestudies.org/0301/Fromme/ (accessed May 2010).

Funk, J.B. and Buchman, D.D. (1996), "Playing violent and computer games and adolescent self-concept", Journal of Communication, Vol. 46 No. 2, pp. 19-32.

Gentry, L. and Calantone, R. (2002), "A comparison of three models to explain shop-bot use on the web”, Psvchologv and Marketing, Vol. 19 No. 11, pp. 945-56.

Hair, J., Anderson, R., Tatham, R. and Black, W. (1998), Multivariate Data Analysis, Prentice Hall, Upper Saddle River, NJ.

Hair, J.F Jr, Black, W.C., Babin, B.J. and Andersen, R.E. (2010), Multivariate Data Analysis: A Global Perspective, 7th ed., Pearson Prentice Hall, Upper Saddle River, NJ.

Helgeson, J.G. and Supphellen, M. (2004), "A conceptual and measurement comparison of selfcongruity and brand personality: the impact of socially desirable responding", International Journal of Market Research, Vol. 46 No. 2, pp. 205-33.

Hoffman, D.L. and Novak, T.P. (2009), "Flow online: lessons learned and future prospects", Journal of Interactive Marketing, Vol. 23 No. 1, pp. 23-34.

Holbrook, M.B. (1982), "Mapping the retail market for esthetic products: the case of jazz records", Journal of Retailing, Vol. 58 No. 1, pp. 114-29.

Holbrook, M.B. and Gardner, M.P. (1998), "How motivation moderates the effects of emotions on the duration of consumption”, Dournal of Business Research, Vol. 42 No. 3, pp. 241-52.

Holbrook, M.B. and Hirschman, E.C. (1982), "The experiential aspects of consumption: consumer fantasies, feelings, and fun”, Journal of Consumer Research, Vol. 9 No. 2, pp. $132-40$.

Hu, L. and Bentler, P.M. (1995), "Evaluating model fit", in Hoyle, R.H. (Ed.), Structural Equation Modelling: Concepts, Issues and Applications, Sage, Thousand Oaks, CA, pp. 76-99. 
Huang, L.-Y. and Hsieh, Y.-J. (2011), "Predicting online game loyalty based on need gratification Modeling UHDM and experiential motives", Internet Research, Vol. 21 No. 5, pp. 581-98.

Igbaria, M. and Iivari, J. (1995), "The effects of self-efficacy on computer usage", Omega: International Journal of Management Science, Vol. 23 No. 6, pp. 587-605.

Jessen, C. (1999), "Computer games and play culture - an outline of an interpretative framework", available at: www.carsten-jessen.dk/compgames.html (accessed May 2010).

Jin, S.-A.A. and Bolebruch, J. (2009), "Avatar-based advertising in second life: the role of presence and attractiveness of virtual spokespersons", The Iournal of Interactive Advertising, Vol. 10 No. 1, pp. 51-60.

Johar, J. and Sirgy, J.M. (1991), "Value-expressive versus utilitarian advertising appeals: when and why to use which appeal”, Iournal of Advertising, Vol. 20 No. 3, pp. 23-33.

Jones, M.A., Reynolds, K.E. and Arnold, M.J. (2006), "Hedonic and utilitarian shopping value: investigating differential effects on retail outcomes", Journal of Business Research, Vol. 59 No. 9, pp. 974-81.

Juul, J. (2001), "Games telling stories? A brief note on games and narratives", International Journal of Computer Game Research, Vol. 1 No. 1, available at: www.gamestudies.org/0101/ Juul-Gts/ (accessed July 2010).

Kang, Y.S., Hong, S. and Lee, H. (2009), "Exploring continued online service usage behaviour: the roles of self-image congruity and regret”, Computers in Human Behaviour, Vol. 25 No. 1, pp. 111-22.

Kim, K.H., Park, J.Y., Kim, D.Y., Moon, H.I. and Chun, H.C. (2002), "E-lifestyle and motives to use online games", Irish Marketing Review, Vol. 15 No. 2, pp. 71-7.

Kivetz, R. (2000), "Hedonic and utilitarian motivations in consumer choice", Advances in Consumer Research, Vol. 27 No. 1, p. 286.

Kline, R.B. (1998), Principles and Practice of Structural Equation Modelling, Guildford Press, New York, NY.

Koo, D.-M. (2009), "The moderating role of locus of control on the links between experiential motives and intention to play online games", Combuters in Human Behaviour, Vol. 25 No. 2, pp. 466-74.

Koufaris, M. (2002), "Applying the technology acceptance model and flow theory to online consumer behaviour", Information Sustems Research, Vol. 13 No. 2, pp. 205-23.

Koufteros, X., Babbar, S. and Kaighobadi, M. (2009), "A paradigm for examining second-order factor models employing structural equation modeling”, International Iournal of Production Economics, Vol. 120 No. 2, pp. 633-52.

Kücklich, J. (2003), "Perspectives of computer game philology", International Journal of Computer Game Research, Vol. 3 No. 1, available at: www.gamestudies.org/0301/Kucklich/ (accessed May 2010).

Li, M., Dong, Z.Y. and Chen, X. (2012), "Factors influencing consumption experience of mobile commerce: a study from experiential view", Internet Research, Vol. 22 No. 2, pp. 120-41.

Liao, Z. and Shi, X. (2009), "Consumer perceptions of internet-based e-retailing: an empirical research in Hong Kong”, Lournal of Services Marketing, Vol. 23 No. 1, pp. 24-30.

López, I. and Ruiz, S. (2011), "Explaining website effectiveness: the hedonic-utilitarian dual mediation hypothesis", Electronic Commerce Research \& Applications, Vol. 10 No. 1, pp. 49-58.

Lu, H.-P. and Wang, S.-M. (2008), "The role of internet addiction in online game loyalty: an exploratory study", Internet Research, Vol. 18 No. 5, pp. 499-519.

Mackay, T., Ewing, M., Newton, F. and Windisch, L. (2009), "The effect of product placement in computer games on brand attitude and recall", International Iournal of Advertising, Vol. 28 No. 3, pp. 423-38. 
INTR

23,2

252

Mackenzie, S.B., Lutz, R.J. and Belch, G.E. (1986), "The role of attitude toward the ad as a mediator of advertising effectiveness: a test of competing explanations", Iournal of Marketing Research, Vol. 23 No. 2, pp. 130-43.

Mathwick, C. and Rigdon, E. (2004), "Play, flow, and the online search experience", Lournal of Consumer Research, Vol. 31 No. 2, pp. 324-32.

Mau, G., Silberer, G. and Constien, C. (2008), "Communicating brands playfully: effects of in-game advertising for familiar and unfamiliar brands", International Journal of Advertising, Vol. 27 No. 5, pp. 827-51.

Miles, M.B. and Huberman, M. (1994), Qualitative Data Analysis: An Expanded Sourcebook, Sage Publications, Thousand Oaks, CA.

Molesworth, M. (2006), "Real brands in imaginary worlds: investigating players' experiences of brand placement in digital games", Journal of Consumer Behaviour, Vol. 5 No. 4, pp. 355-66.

Murray, K.B. and Bellman, S. (2011), "Productive play time: the effect of practice on consumer demand for hedonic experiences", Journal of the Academv of Marketing Science, Vol. 39 No. 3, pp. 376-91.

Myers, D. (1990), “Computer game genres”, Play and Culture, Vol. 3, pp. 286-301.

Newman, J. (2004), Video Games, Taylor Francis Group, Routledge, London.

$\mathrm{Ng}$, S. (2012), "Regulatory focus and preference reversal between hedonic and utilitarian consumption", Journal of Consumer Behaviour, Vol. 11 No. 1, pp. 81-8.

Nicovich, S.G. (2005), "The effect of involvement on ad judgment in a video game environment the mediating role of presence", Iournal of Interactive Advertising, Vol. 6 No. 1, pp. 29-39.

Nunnally, J.C. (1978), Psychometric Theory, McGraw-Hill, New York, NY.

Ong, C. (2004), "Videogame behaviour: a two stage model of congruity and evaluation", A dissertation submitted in partial fulfilment of the requirements for the degree of Bachelor of Commerce (Honours) in Information Systems, The University of Auckland, Auckland, December.

Overby, J.W. and Eun-Ju, L (2006), "The effects of utilitarian and hedonic online shopping value on consumer preference and intentions", Journal of Business Research, Vol. 59 No. 1011, pp. 10-11.

Prensky, M. (2001), Fun, Play and Games: What Makes Games Engaging, Digital Game-Based Learning McGraw-Hill, New York, NY.

Prugsamatz, S., Lowe, B. and Alpert, F. (2010), "Modelling consumer entertainment software choice: an exploratory examination of key attributes, and differences by gamer segment", Journal of Consumer Behaviour, Vol. 9 No. 5, pp. 1479-838.

Quester, P.G., Karunaratna, A. and Goh, L.K. (2000), "Self-congruity and product evaluation: a cross-cultural study", Journal of Consumer Marketing, Vol. 17 No. 6, pp. 525-35.

Raynolds, K.E., Jones, M.A., Musgrove, C.F. and Gillison, S.T. (2012), “An investigation of retail outcomes comparing two types of browsers", Iournal of Business Research, Vol. 65 No. 8, pp. 1090-5.

Rintamäki, T., Kanto, A., Kuusela, H. and Spence, M.T. (2006), "Decomposing the value of department store shopping into utilitarian, hedonic and social dimensions: evidence from Finland", International Iournal of Retail \& Distribution Management, Vol. 34 No. 1, pp. 6-24.

Rosenberg, M. (1979), Conceiving the Self, Basic Books, New York, NY.

Scarpi, D. (2012), "Work and fun on the internet: the effects of utilitarianism and hedonism online", Iournal of Interactive Marketing, Vol. 26 No. 1, pp. 53-67.

Sirgy, J.M. (1982), "Self-concept in consumer behaviour: a critical review", Lournal of Consumer Research, Vol. 9 No. 3, pp. 287-300.

Sirgy, J.M., Grewal, D., Mangleburg, T.F., Park, J., Chon, K.S., Caliborn, C.B., Johar, J.S. and Berkman, H. (1997), "Assessing the predictive validity of two methods of measuring selfimage congruence", Journal of the Academy of Marketing Science, Vol. 25 No. 3, pp. 229-41. 
Sirgy, J.M., Lee, D.J., Johar, V. and Tidwell, J. (2008), "Effect of self-congruity with sponsorship on Modeling UHDM brand loyalty", Iournal of Business Research, Vol. 61 No. 10, pp. 1091-7.

Thong, J.Y. and $\mathrm{Xu}, \mathrm{X}$. (2012), "Consumer acceptance and use of information technology: extending the unified theory of acceptance and use of technology", MIS Quarterlv, Vol. 36 No. 1 , pp. $157-78$.

Trujillo, C.A., Barrios, A., Camacho, S.M. and Rosa, J.A. (2010), "Low socioeconomic class and consumer complexity expectations for new product technology", Iournal of Business Research, Vol. 63 No. 6, pp. 538-47.

UKIE (2011), "The association for UK Interactive Entertainment", available at: www. ukie.info (accessed 22 December 2011).

Van der Heijden, H. (2004), "User acceptance of hedonic information systems”, MIS Quarterlv Vol. 28 No. 4, pp. 695-704.

Venkatesh, V. (2000), "Determinants of perceived ease of use: integrating control, intrinsic motivation, and emotion into the technology acceptance model", Information Svstems Research, Vol. 11 No. 4, pp. 342-65.

Venkatesh, V. and Davis, F.D. (1996), "A model of the antecedents of perceived ease of use: development and test”, Decision Science, Vol. 27 No. 3, pp. 451-81.

Venkatesh, V., Morris, M.G., Davis, G.B. and Davis, F.D. (2003), "Consumer acceptance of information technology: toward a unified view", MIS Quarterlv, Vol. 27 No. 3, pp. 425-78.

Vijayasarathy, L.R. (2004), "Predicting consumer intentions to use on-line shopping: the case for an augmented technology acceptance model”, Information \& Management, Vol. 41 No. 6, pp. 747-62.

Vorderer, P. (2003), "Explaining the enjoyment of playing video games: the role of competition", Proceedings of the Second International Conference on Entertainment Computing, Carnegie Mellon University Pittsburgh, Pittsburgh, PA, 8-10 May.

Voss, K.E., Spangenberg, E.R. and Grohmann, B. (2003), "Measuring the hedonic and utilitarian dimensions of consumer attitude", Iournal of Marketing Research (IMR), Vol. 40 No. 3, pp. $310-20$.

Walther, B.K. (2003), "Playing and gaming. Reflections and classifications", International Journal of Computer Game Research, Vol. 3 No. 1, available at: www.gamestudies.org/0301/ Walther/ (accessed May 2010).

Wang, L.C., Baker, J., Wagner, J.A. and Wakefield, K. (2007), “Can a retail web site be social?”, Lournal of Marketing, Vol. 71 No. 3, pp. 143-57.

Wolfinbarger, M. and Gilly, M.C. (2001), "Shopping online for freedom, control and fun", California Management Review, Vol. 43 No. 2, pp. 34-55.

Yang, K. (2010), "Determinants of US consumer mobile shopping services adoption: implications for designing mobile shopping services", Iournal of Consumer Marketing, Vol. 27 No. 3, pp. 262-70.

Yin, R.K. (1994), Case Study Research, Sage Publications, Thousand Oaks, CA.

\section{Further reading}

Bardhi, F. and Arnould, E.J. (2005), "Thrift shopping: combining utilitarian thrift and hedonic treat benefits", Journal of Consumer Behaviour, Vol. 4 No. 4, pp. 223-33.

Chitturi, R., Raghunathan, R. and Mahajan, V. (2008), "Delight by design: the role of hedonic versus utilitarian benefits", Lournal of Marketing, Vol. 72 No. 3, pp. 48-63.

(The Appendix follow overleaf.) 
INTR

23,2

254

\section{Appendix}

Note

$\begin{array}{llll}\text { Purchase } & \text { How often do you buy games? } & \text { PB1 } 4\end{array}$

How often do you buy the following game types?

$\begin{array}{ll} & \text { How many games do you own in total? } \\ \text { Usage } & \text { How often do you play games on each of the following platforms? }\end{array}$

$\begin{array}{rll}\text { Action } & \text { PB2 } & \mathbf{1} \\ \text { Adventure } & \text { PB3 } & \mathbf{1} \\ \text { Driving } & \text { PB4 } & \mathbf{1} \\ \text { Fighting } & \text { PB5 } & \mathbf{1} \\ \text { Children } & \text { PB6 } & 2 \\ \text { Educational } & \text { PB7 } & 2 \\ \text { ying Game) } & \text { PB8 } & \mathbf{1} \\ \text { ying Game) } & \text { PB9 } & \mathbf{1} \\ \text { Simulation } & \text { PB10 } & \mathbf{1} \\ \text { Strategy } & \text { PB11 } & \mathbf{1} \\ \text { Sports } & \text { PB12 } & \mathbf{1} \\ & \text { PB13 } & 2\end{array}$

$\begin{array}{lll}\mathrm{PC} / \mathrm{MAC} & \text { PU1 } & 1\end{array}$

Xbox PU2 1

PlayStation $\quad$ PU3 1

Connected to the Internet PU4 1

PU5 1

In a typical week, how many hours do you play games? $\quad$ PU6 4

How long have you been playing games?

PU7 4

How often do you play the following game types?

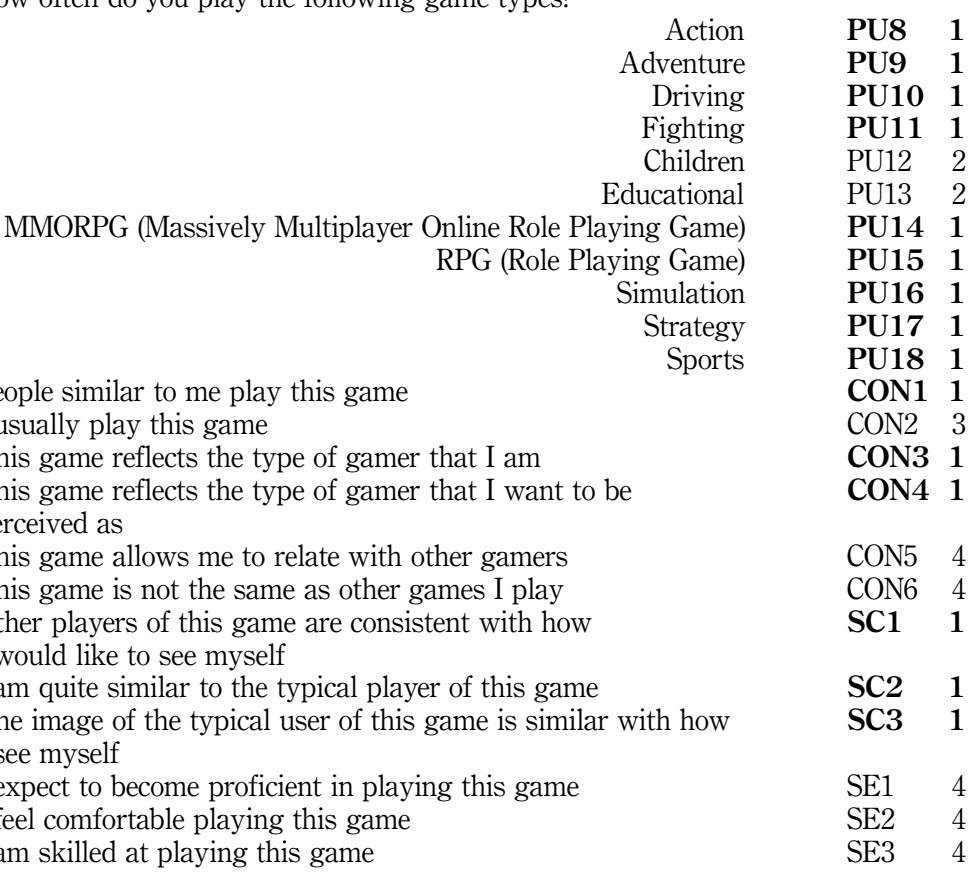

Table AI.

Self-Concept People similar to me play this game

This game reflects the type of gamer that I am

This game reflects the type of gamer that I want to be perceived as

This game allows me to relate with other gamers

This game is not the same as other games I play

Self-Congruity Other players of this game are consistent with how

I would like to see myself

I am quite similar to the typical player of this game

The image of the typical user of this game is similar with how

I see myself

Self-Efficacy I expect to become proficient in playing this game

SE3 4

Questionnaire items

(continued) 
I know how to do what I want to do with this game

I know more about the game than most other people who play

this game

I can play this game if I can call someone for help if I get stuck

I can play this game if I have the manual for reference

I can play this game if I have a lot of time to practice

I can play this game if I have the built-in help assistance

I can play this game if I have never played a similar game

like it before

I can play this game if I have never played it before.

I can play this game if I have not seen anyone play it before.

I can play this game if I have played a similar game like this one before.

I can play this game if I have seen someone else play it before I play.

I can play this game if someone else has helped me to get started.

I can play this game if someone showed me how to play it first.

I can play this game if there was no one to help me to show me what to do.

Perceived Enjoyment

When I play this game it allows me to master a skill.

When I play this game it gives me a feeling of satisfaction.

When I play this game it gives me a feeling of diversion.

When I play this game it gives me a feeling of amusement

When I play this game the experience is enjoyable

When I play this game the experience is interesting

When I play this game the experience is exciting

When I play this game the experience is fun.

The actual process of playing this game is pleasant.

When I play this game it makes me feel spontaneous.

When I play this game it makes me feel unimaginative.

When I play this game it makes me feel flexible.

When I play this game it makes me feel creative.

When I play this game it makes me feel playful.

When I play this game it makes me feel unoriginal.

When I play this game it makes me feel uninventive.

Perceived Ease I find it easy to get this game to do what I want it to do.

Of Use
I find it easy to learn the rules of this game

I find it easy to operate the controls of this game

I find the system interface easy to use

I find this game easy to use

Interacting with this game does not require a lot of mental effort

It has been easy for me to become skilful at playing this game

It has been easy to interact with this game

Learning to play this game has been easy for me

My interaction with this game has been clear and understandable

This game has been flexible to interact with

The control of the in-game character/s has been easy to use

This game has been easy to master

Overall I believe that this game has been easy to play

Overall I believe that this game has been easy to use
SE4 4

SE5 4

SE6 4

SE7 4

SE8 4

SE9 3

SE10 3

SE11 4

SE12 4

SE13 4

SE14 1

SE15 1

SE16 1

SE17 4

ENJ1 4

ENJ2 4

ENJ3 4

ENJ4 1

ENJ5 1

ENJ6 1

ENJ8 1

ENJ9 4

ENJ10 4

ENJ11 3

ENJ12 4

ENJ13 4

ENJ14 4

ENJ15 3

ENJ16 3

ENJ7 3

PE1 4

PE2 4

PE3 1

PE4 1

PE5 1

PE6 4

PE7 4

PE8 4

PE9 4

PE10 4

PE11 4

PE12 4

PE13 4

PE14 4

PE15 4

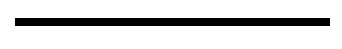


INTR

23,2

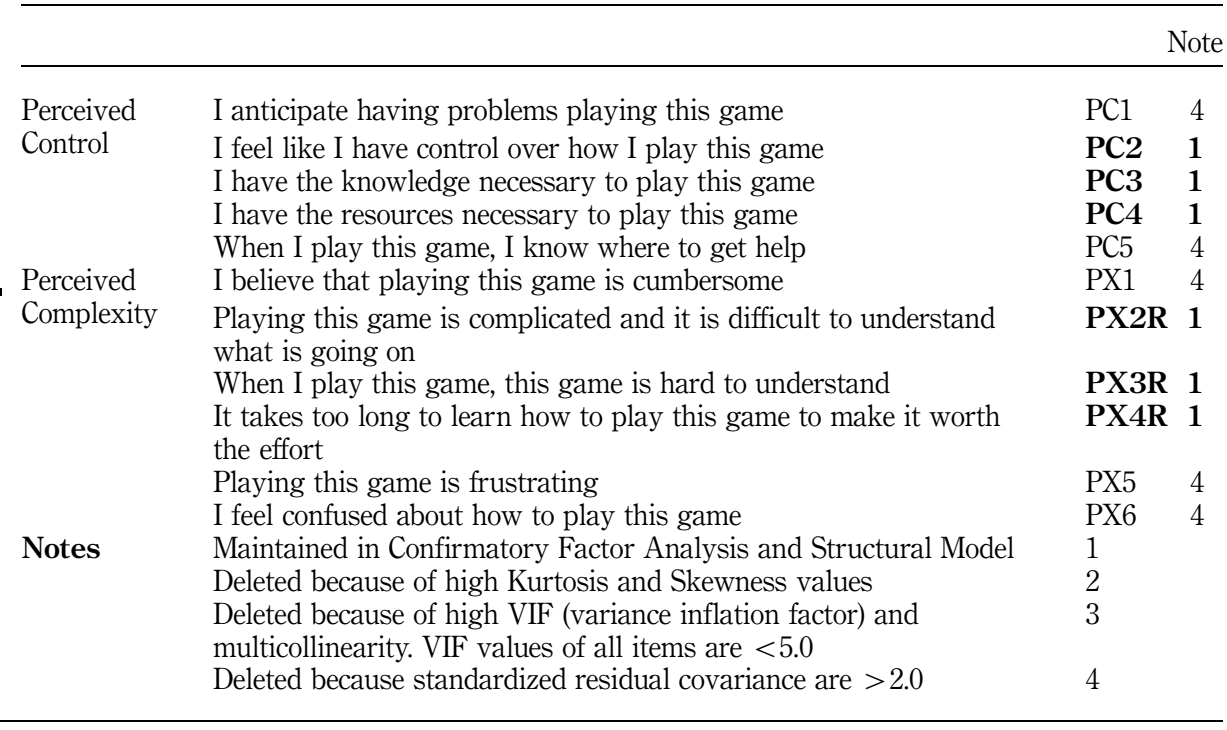

\section{Corresponding author}

Robert Davis can be contacted at: rdavis@unitec.ac.nz

To purchase reprints of this article please e-mail: reprints@emeraldinsight.com Or visit our web site for further details: www.emeraldinsight.com/reprints 
This article has been cited by:

1. Robert Mihan, Yvonne Anisimowicz, Richard Nicki. 2015. Safer with a partner: Exploring the emotional consequences of multiplayer video gaming. Computers in Human Bebavior 44, 299-304. [CrossRef]

2. Hsiu-Sen Chiang, Kuo-Lun Hsiao. 2015. YouTube stickiness: the needs, personal, and environmental perspective. Internet Research 25:1, 85-106. [Abstract] [Full Text] [PDF]

3. Wilson Ozuem, Michael BorrelliConsumer Attitudes toward Online Video Game Purchases 83-112. [CrossRef] 